\title{
The real Devario browni from the Irrawaddy River basin, and the new Devario ahlanderi from the Salween River basin in Myanmar (Teleostei: Cyprinidae: Danioninae)
}

\author{
SVEN KULLANDER ${ }^{1,2} \&$ MICHAEL NORÉN ${ }^{1,3}$ \\ ${ }^{1}$ Department of Zoology, Swedish Museum of Natural History, PO Box 50007, SE-104 05 Stockholm, Sweden \\ 2 "sven.kullander@nrm.se; (1) https://orcid.org/0000-0001-6075-0266

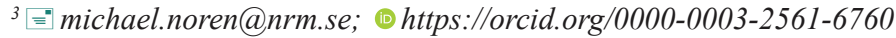

\begin{abstract}
Specimens of Devario from a tributary to the Salween River in Myanmar initially identified as Devario browni but with a different colour pattern, were subjected to a comparative morphological analysis with syntypes and other specimens of $D$. browni from near its putative type locality. The Salween sample was recognised as representing a distinct species, here named Devario ahlanderi. No significant morphometric differences were found between D. ahlanderi and D. browni. The type series of Devario ahlanderi differed from D. browni and most other species of Devario in the presence of 14 vs 12 circumpeduncular scale rows. Devario ahlanderi, D. browni, and D. fangae shared subadult colour pattern. Adult D. ahlanderi differed from adult D. browni in the trunk colour pattern, consisting of rows of dark blotches or short vertical bars. In D. browni, the flank colour pattern consisted of horizontal dark stripes, the middle of which (the P stripe) frequently diverged anteriorly, enclosing a small light blotch. Specimens previously reported as $D$. browni from the upper Salween River basin in Yunnan differed slightly in colour pattern, and may represent a distinct species. Devario ahlanderi shared spotted colour pattern with that of one ontogenetic state in D. kysonensis, except that a row of spots marking the P1 stripe in D. kysonensis was absent in D. ahlanderi. The minimum genetic distance between $D$. ahlanderi and congeneric species varied from 2.1 to $5 \%$ in the $m t$-col gene.
\end{abstract}

Key words: colour pattern, freshwater, morphology, South Asia, species discrimination, taxonomy

\section{Introduction}

The cyprinid fish genus Devario Heckel, 1843 comprises 42 named species distributed in South and Southeast Asia (Kullander, 2001; Kottelat, 2021). Devario comprises predominantly elongate shoaling fishes found in small fast-flowing hill streams, but some species are found in rivers and one species, Devario auropurpureus (Annandale, 1918), is abundant in Inle Lake in eastern Myanmar. Adult size is commonly 40-50 mm SL; 82 mm SL recorded for D. anomalus Conway, Mayden and Tang, 2009 (Conway et al. 2009). The genus shares with some other danionine genera-Chela Hamilton, 1822, Laubuka Bleeker, 1859, Microrasbora Annandale, 1918, and Betadevario Pramod, Fang, Rema Devi, Liao, Jameela Beevi and Kullander, 2010 - the presence of supraorbital recesses filled with neuromasts, but in contrast to those genera the paired maxillary barbel is absent or very short in Devario. Several phylogenetic studies recovered Devario as monophyletic, including distinct species groups, but the species representation was limited (Pramod et al. 2010; Kullander et al.; 2017; Sudasinghe et al. 2020; Tang et al. 2010). Kottelat $(2013,2020)$ treated Inlecypris Howes, 1980, as a valid genus, comprising Devario auropurpureus (type species), D. jayarami (Barman, 1985), D. shanensis (Hora, 1928), and D. maetaengensis (Fang, 1997).

Ten species of Devario were reported from Myanmar, mainly from the Irrawaddy River basin (Kullander, 2017). Three of these species were described from localities in the Salween River basin in Myanmar: Devario sondhii (Hora and Mukerji, 1934), D. auropurpureus, and D. jayarami). Hora and Mukerji (1934) reported D. aequipinnatus M'Clelland, 1839) from the Salween River basin, but this species is restricted to the Ganges and Brahmaputra River basins (Kullander et al., 2017). Devario browni (Regan, 1907) and D. shanensis, with type localities in Myanmar, were reported from the Salween River basin in P.R. China (Fang 2000). 
Without citing vouchers, Ramananda et al. (2014) listed Devario browni, and six more nominal species of Devario from the Chindwin basin. None of those species was ever recorded from the Chindwin River basin.

Collections made in 2008 in the Salween River basin in north-eastern Myanmar yielded specimens of a species of Devario characterised by a distinctive colour pattern composed of numerous dark spots laterally on the trunk, similar to Devario kysonensis (Nguyen, Nguyen and Mua, 2010) in the Mekong (Laos) and Song Lam (Vietnam) River basins, recently re-described by Kottelat (2020). The sample of spotted specimens was initially determined as Devario browni sensu Fang (2000). This identification was adopted by Kullander (2017) and Kullander et al. (2017). Revision of this sample and comparison with syntypes of Devario browni showed, however, that the initial attribution was incorrect. This prompted us to revise $D$. browni on the basis of syntypes and other relevant samples from the upper Irrawaddy and Salween River basins.

\section{Material and methods}

All specimens examined were already available in museum collections. Specimen metadata are given in Appendix 1. Figure 1 shows collecting sites of target taxa. Except for a small number preserved in $95 \%$ ethyl alcohol, specimens collected in 2008 were fixed in formalin in the field, eventually transferred to $70 \%$ ethanol for permanent storage in the fish collection of the Swedish Museum of Natural History, Stockholm (NRM). Additional referred material is deposited in the collection of the Natural History Museum, London (BMNH), and the Zoological Museum of Yunnan University, Kunming (ZMYU). Notes made by Fang Fang in 1997 were available for specimens in the collection of the Zoological Survey of India, Kolkata (ZSI). ZMYU specimens were in suboptimal condition of preservation, making accurate data recording difficult; body curved in most specimens, fins folded and attached to the body, fin rays attached to each other, and many scales lost from some specimens; data used here with reservation. NRM material included local market specimens and strongly curved specimens, some of which were excluded from data recording.

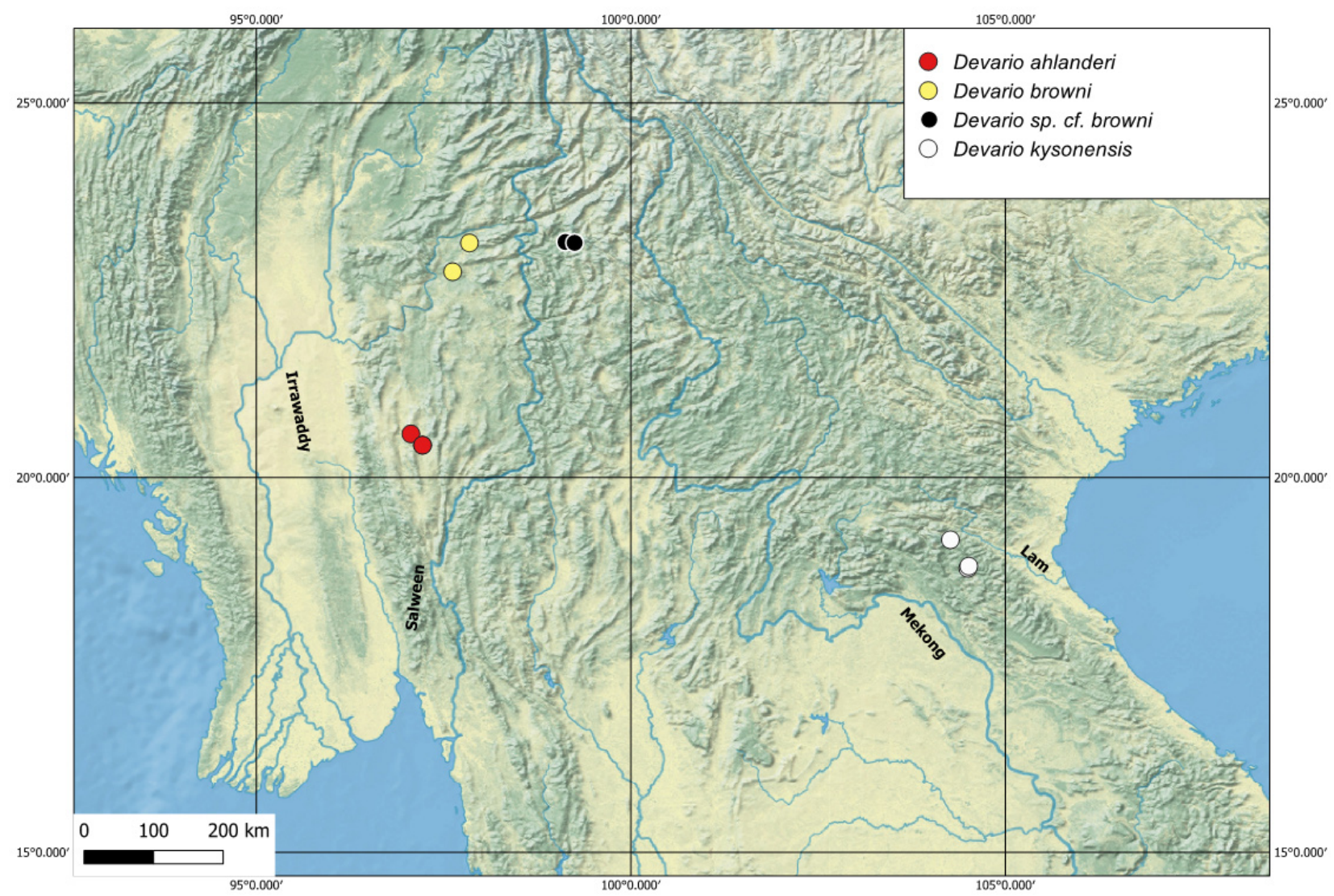

FIGURE 1. Map of sampling sites of Devario ahlanderi, D. browni, Devario cf. browni, and D. kysonensis. 
Measurements were recorded with digital callipers to a precision of $0.1 \mathrm{~mm}$. Meristic data and measurements were recorded according to Fang (1997). Colour pattern terminology followed Fang (1997, 1998). Vertebrae and number or fin rays in median fins were counted on X-radiographs made with a Philips MG-105 low voltage X-ray unit and Kodak X-Omat V plates, or a Kevex 130kVP microfocus X-ray source and a Samsung/Rayence 1717 inch DR panel. The last ray in the dorsal and anal fins was tightly joined to the preceding ray and shared a pterygiophore with it; it was recorded as a half-ray, following the annotation used by Kottelat (2020). The recorded number of precaudal vertebrae includes the Weberian apparatus (assumed to contain four centra). Statistical parameters were calculated using SYSTAT v.13. (SYSTAT 2009). The map of collection sites was produced using QGIS, v. 3 (https:// qgis.org), and map layers from Natural Earth (https://www.naturalearthdata.com/).

Specimens were assigned a priori to taxa based on colour pattern and locality, and those samples subjected to comparative analyses of colour pattern, proportional measurements, and meristic data. The null hypothesis was that the spotted sample from the Salween River basin is morphologically indistinguishable from the type series of Devario browni and specimens from near the type locality of D. browni, representing the same species; if failed, distinguishing characters of the Salween sample would be tested against distinguishing characters among other species of Devario.

\section{Results}

Type series and type locality of Devario browni. The original description of Devario browni (as Danio browni) was based on nine specimens up to $70 \mathrm{~mm}$ total length with locality 'Northern Shan States, Upper Burma' (Regan 1907). Regan's morphological description is general and could be applied on several species of Devario, but the description of the colour pattern of $D$. browni stands out: 'Three to five dark bluish longitudinal lateral stripes, the middle one of which broadens out anteriorly and usually becomes double, forming a loop on the middle of the side above the ventral fins, whilst the stripe below curves upwards in front of the loop'.

The type series of Devario browni was collected by John Coggin Brown, a British geologist, appointed in 1905 as Assistant Superintendent in the Geological Survey of India, located in Kolkata. He was deputed to Lashio in 1906 and in 1907 sent on a first mission to Yunnan (Northern Mine Research Society 1963). A more precise locality seems not to be hoped for, but it can be reasonably assumed that Coggin Brown was stationed in Lashio, then the capital of the Northern Shan State, and consequently in the Irrawaddy River basin. Five syntypes (F1872/1) were listed by Menon and Yazdani (1963) as present in the ZSI. Five specimens in the BMNH with collection data 'N. Shan States' probably represent the remaining four syntypes, although they were labelled as types of Danio aequipinnatus, donated by Annandale (Nelson Annandale, Director of the Zoological Survey of India, 1907-1924). The catalogue number, 1907.10.22.1-4, supports this identification. The BMNH sample consisted of three larger specimens, 43.7-57.0 mm SL - the largest $72.9 \mathrm{~mm}$ in total length (Fig. 2) - and two much smaller specimens, 18.6 and $30.0 \mathrm{~mm}$ SL, respectively. It seemed that the smallest specimen may have been overlooked or otherwise excluded from the original description. Supernumerary specimens are not uncommon among older fish objects in the BMNH, and were reserved for potential exchange. The smaller specimens were in a poor state of preservation, and were not included in the morphological analysis here. The five ZSI syntypes had a similar size range; 16.4 (2), 28.5, 30.3, $50.5 \mathrm{~mm}$ (as measured by Fang (unpublished notes).

The two larger BMNH syntypes were decoloured, pale brown on yellowish white ground, without strong melanophore expressions. The fins were damaged, and the body soft, but otherwise judged to have maintained natural shape. The largest specimen was a male with tubercles present on the pectoral fin. Both specimens exhibited faint remains of the melanophore pattern along the side of the body. The P stripe was present, extending posteroanteriorly from the end of the caudal peduncle, gradually expanding until reaching a vertical through the tip of the pectoral fin, where forked into a superior and inferior branch separated by two small light spots in anteroposterior sequence; from there the P stripe was extended cephalad by three short dark bars lined with light ground colour. The light anterior margin of the P stripe combined with the light I+1 and I-1 interstripes. Our observations on the P stripe in the syntypes agreed with Regan's description.

Mukerji (1934) synonymised Devario browni with D. aequipinnatus: 'I have examined the type-specimens of [Danio browni] preserved in the collection of the Indian Museum, and have found that D. browni is strikingly similar to $D$. aequipinnatus. I do not find any stable character that can be taken into consideration in differentiating 
Regan's species from the other. D. aequipinnatus is such a variable species, as I find from an examination of large series of specimens from various places in India, Burma and Siam, that it seems impossible to recognise D. browni [as] a distinct form'. Mukerji's paper was delayed and appeared after the affirmative statement by Hora and Mukerji (1934). This synonymy was adopted by later authors until Fang (2000) resurrected $D$. browni based on examination of the syntypes and more recently collected specimens from the Irrawaddy River basin Myanmar and the Salween River basin in P.R. China, but she did not present a full revision of the species.

Barman (1991) treated Devario browni as a junior synonym of Devario aequipinnatus. His enumeration of material examined of D. aequipinnatus includes four specimens, ZSIF 1876/1, 32.0-45.0 mm, with Northern Shan States as geographical origin, and J.C. Brown as provenance. The nomenclatural status of these specimens has not been examined. Selection of a lectotype of Danio browni from specimens present in the BMNH and with reasonable certainty examined by Regan, eliminates all other candidates for a name-bearing type specimen.

Although the precise locality and date of collection are not known for the type series of Devario browni, and the location in the Irrawaddy River basin remains an assumption, it seemed likely that the specimens were collected in the Irrawaddy River basin, as also concluded by Fang (2000), and more precisely in or near Lashio in the Northern Shan States where Coggin Brown was stationed. Nonetheless, there is an element of uncertainty in this reasoning as headwaters of the Salween extend through Northern Shan States to Yunnan, and Coggin Brown may have made other wider-ranging excursions from Lashio aside from the mission to Yunnan in 1907. Hora (1929) described Nemachilus acuticephalus and N. paucifasciatus collected by Coggin Brown in 1911 in the Hwe-gna-sang River, described by Hora as located in Pazi Township, Mong Long Subdivision, Hsipaw State, a tributary of the Madeya River with mouth in the Irrawaddy River a short distance above Mandalay. Chaudhuri (1911) and Menon and Yazdani (1963) listed fish specimens collected by Coggin Brown in 1910 in Bhamo, and in Tali Fu (=Dali Lake) in Yunnan in 1909 and 1910. Chaudhuri also described Nemachilus salmonoides from "Mongpan, southern Yunnan, a locality identified by Kottelat (2012) as Mengban, $23^{\circ} 07^{\prime} \mathrm{N} 100^{\circ} 23^{\prime} \mathrm{E}$, in the Mekong River basin. Menon and Yazdani (1963) gave the dates for the holotypes of Nemachilus acuticephalus and N. paucifasciatus as April 1908, and April 1910, respectively. No documentation was available on collections made by Coggin Brown in 1907.

Species discrimination. Species identity of the Salween and Irrawaddy samples was not corroborated. Morphometric and meristic data (Appendix 2), and comparison of colour patterns showed discrete differences between Devario browni from the Irrawaddy River basin and the Salween sample in the adult colour pattern and number of circumpeduncular scale rows (Appendix 2), which justified recognition of the latter as a different species, here named Devario ahlanderi. Significant differences in the distance measurements remain contentious because of the very small sample sizes. Counts of scales and fin rays overlapped, and were not significantly different $(\mathrm{p}>0.05)$ (Appendix 2) except for the count of 14 circumpeduncular scales in all specimens of $D$. ahlanderi vs 12 in all specimens of D. browni.

Each species presented a distinctive adult colour pattern (Figs 2-4). In both, the P stripe expanded in width cephalad, and more so close to the anterior termination, and there was a distinct light margin (The I+1 and I -1 interstripes) to the P stripe. In D. browni the expanded anterior portion was filled with brown colour, containing one or two small light spots or not. In $D$. ahlanderi, the corresponding expansion was filled with brown blotches or short vertical bars margined with light perimeter. In the large adults, the blotches/bars conformed to positions of Bar 1 (cleithral spot), Bar 2 (integer or split vertically), and Bars 3-7 in barred Devario (cf. Fang, 1998, fig. 1).

Specimens from Yunnan, identified by Fang (2000) as D. browni, had a colour pattern dominated by anteroposterior stripes, similar to $D$. browni from the Irrawaddy River basin, but the P stripe was not or only slightly widened anteriorly, and the characteristic closed loop pattern and enclosed light spot was absent. Figure 5 A shows the dominant pattern in specimens from the Nangun River, with narrow P stripe and terminated by a short acute flexion. One specimen from the Qingshui River showed a pattern similar to that in young D. browni from the Irrawaddy basin (Fig. 5 B). Other specimens showed elements similar to the pattern in D. browni, but with very small anterior blotch (Fig. 5 C). Two specimens had two very large enclosed light centres ringed with dark colour, but this pattern was formed by bars connecting the P-1 and P stripe, and not by forking of the P stripe (Fig. 5 D). The distinct ocellar pattern was present in one specimen only (Fig. 5 E). The variation in colour pattern suggested that the specimens from Yunnan represented one or more undescribed species.

The Yunnan sample did not differ in morphometric and meristic data from the sample from the Irrawaddy River basin, including the presence 12 circumpeduncular scale rows (Appendix 2). The Yunnan specimens differed from D. browni samples in the presence of two rows of prominent tubercles on the lower jaw in both sexes and at all 
sizes down to the shortest specimen, $34.6 \mathrm{~mm}$ SL. Because of the very different state of preservation from the other samples, the possibility that the distinct tubercles were a preservation artefact could not be excluded.

Material for genetic analysis was not available of Devario browni. In a phylogenetic analysis of Devario based on the mitochondrial cytochrome c subunit I gene ( $m t-c o l)$, Kullander et al. (2017) recovered D. browni $(=D$. ahlanderi) clustering with species from the Irrawaddy River basin $-D$. fangae Kullander, 2017, D. kakhienensis Anderson (1878), D. cf. myitkyinae. The uncorrected minimum $p$-distances separated $D$. browni $(=D$. ahlanderi) from $D$. kakhienensis by $2.1 \%, D$. fangae by $2.7 \%, D$. cf. myitkyinae by $5.0 \%$, and from congeneric species in other river basins by up to $5.0 \%$

Genus-wide comparison. Adult colour pattern distinguished Devario browni from all other species of Devario. Devario ahlanderi was different from all other species of Devario so far analysed in the $m t$-coI gene (Kullander et al. 2017), and similar in colour pattern only to Devario kysonensis. Based on the description by Kottelat (2020: fig. 1 a), D. kysonensis shares the posteroanterior widening and light lining of the P stripe in juveniles with $D$. ahlanderi, D. browni, and D. fangae, and with D. ahlanderi alone the spotted adult colour pattern. The fragmentation of the $\mathrm{P}$ stripe into vertical bars or blotches is present from smaller sizes in D. kysonensis (about 25-30 mm (Kottelat 2020, fig. 1 a; p. 558) than in D. ahlanderi (about $40 \mathrm{~mm} \mathrm{SL}$ ). As illustrated by Kottelat (2020: fig. 1), young specimens of $D$. kysonensis possess an uninterrupted $\mathrm{P}$ stripe replaced by short vertical bars anteriorly on the flank, and dark spots in rows in the $\mathrm{P}+1$ and $\mathrm{P}-1$ stripes up to about $45 \mathrm{~mm} \mathrm{SL}$; in most larger specimens of $D$. kysonensis, about $50-60 \mathrm{~mm} \mathrm{SL}$, the $\mathrm{P}$ stripe is absent except on the caudal peduncle but the spots in the $\mathrm{P}+1$ and $\mathrm{P}-1$ stripes remain, although relatively smaller than in smaller specimens. One large specimen of D. kysonensis, $52.6 \mathrm{~mm}$ SL however, retains the colour pattern of small specimens (Kottelat 2020: fig. 1f). Specimens available of $D$. ahlanderi differed from $D$. kysonensis in the presence of an integer P-1 stripe, contrasting with $D$. kysonensis in which the P-1 stripe is composed of a row of dark spots (cf. Kottelat 2020, figs 1b-h).

In In Devario kakhienensis, juveniles were striped but lacked the contrasting light margin of the P stripe characteristic of juveniles of the other species. In subadults and adults of $D$. kakhienensis the P stripe was only one scale wide at its widest and pigmentation at the anterior termination did not form a loop (Fang, 1997: figs 4-5). In $D$. fangae, the P stripe was uniform in width or only slightly widened anteriorly (Kullander 1917: figs 1, a, c). Juvenile D. fangae had either a straight, uniform $\mathrm{P}$ stripe lined with light interstripes, or a more or less expanded P stripe (Kullander 2017: fig. 2 a, b) as in juveniles of D. ahlanderi (Fig. 6), D. browni, and D. kysonensis.

Proportional measurements of Devario ahlanderi and D. browni overlapped with those of $D$. kysonensis reported by Kottelat (2020), except in body depth and caudal peduncle length; and all measurements with those of $D$. fangae, reported by Kullander (2017). Proportional measurements of the Yunnan sample overlapped with those of $D$. ahlanderi and D. browni, except for two specimens with very short snout.

The number of circumpeduncular scale rows were reported as 12 (one with 14) in D. kysonensis (Kottelat 2020). Circumpeduncular scale counts reported from species of Devario ranged from 10 in Devario apopyris Fang and Kottelat (1999) to 15 in D. acrostomus Fang and Kottelat (1999), 15-16 in D. memorialis Sudasinghe, Pethiyagoda and Meegaskumbura (2020), and 15-17 in D. devario (Hamilton, 1822) (Kullander et al. 2017). Most species had 12; among 22 valid species of Devario described or re-described after 1996, 15 had 12 circumpeduncular scale rows. Devario coxi Kullander, Norén and Mollah (2017), D. fangfangae Kottelat, 2000, with14-16), and D. xyrops Fang and Kullander 2009, with 12-14 were the only species with 14 circumpeduncular scale rows.

Devario ahlanderi, D. browni, and D. fangae were the only species of Devario in which the light interstripes I and I-1 connected in front of the P stripe, and in some specimens even forming an almost closed elongate ring. In D. kysonensis the P stripe is interrupted before reaching the most anterior extension (Kottelat 2020: fig. 1a)

\section{Species descriptions}

\section{Devario browni (Regan, 1907)}

Lectotype BMNH 19071907.10.22.1, Adult male. 57.0 mm SL (Fig. 2A); paralectotypes BMNH 1907.10.22.2-4, ZSI F1872/1. The lectotype designation here is motivated by the uncertainty about which specimens belong in the type series, and the taxonomic uncertainty resulting from previous misidentifications. Data in this description and lectotype designation fulfil paragraph74.7 and as far as relevant Recommendations A, C, D, E, and F of the International Code of Zoological nomenclature (International Commission for Zoological Nomenclature, 1999). 


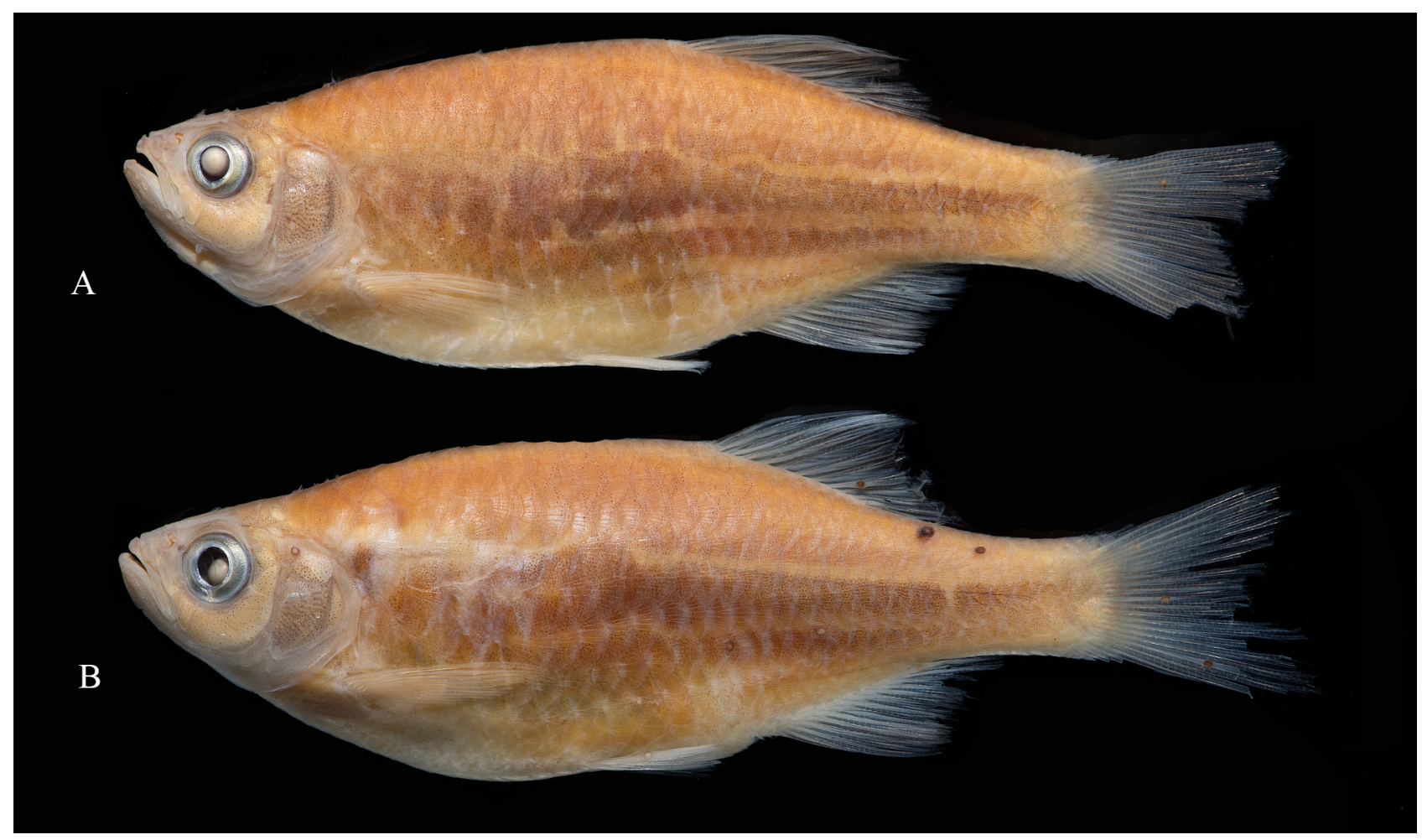

FIGURE 2. Devario browni. BMNH 1907.10.22:1-4; A, Lectotype, male 57.0 mm SL; B, Paralectotype, female, 52.5 mm SL; Northern Shan States.

Revised definition. Distinguished from all other species of Devario by the shape of the P stripe: gradually expanding posteroanteriorly, either forming a uniform brown blotch anteriorly, or P stripe diverging anteriorly, forming a brown blotch enclosing a small light spot or two contiguous small light spots.

Description based on referred specimens and type series. Representative specimens are shown in Figures 2-3. Morphometric and meristic data are given in Appendix 2.

Body laterally compressed, elongate; sexes significantly different in body depth (ANCOVA, $p>0.05$, but only eight adult specimens were available. Predorsal contour ascending in straight line, sloping posteriorly from anterior dorsal-fin insertion. Prepelvic contour strongly curved; chest conspicuously compressed below pectoral fin, but not keeled. Snout short, rounded in dorsal aspect, subtriangular in lateral aspect, about as long as eye diameter. Infraorbital process broader than high, with truncate distal margin which may be slightly irregular. Danionine notch caudally margined by well-developed anteromediad projecting laminar dentary process. Skin thin or absent from distal part of infraorbital process, dentary process, and anterior margin of supraorbital. Mouth terminal, obliquely directed upwards. Bony knob at dentary symphysis minor, fitting in shallow depression in upper jaw. Blunt tubercles present in adults in 1-2 (males) or 1 row (females) on lateral adoral surface of dentary, and additional scattered tubercles anteriorly on dentary. Maxilla reaching to below anterior margin of orbit. Jaws equal in anterior extension; lower jaw ending anteriorly at horizontal through middle of eye. In large males, bands of strong, densely arranged sharp-tipped conical tubercles on anterior seven rays of pectoral fin; pectoral-fin tubercles absent in females, but one specimen, $59.8 \mathrm{~mm}$ SL potentially female with spaced tubercles on three anterior pectoral fin rays and relatively deep body. Rostral barbel short, reaching slightly beyond junction of lacrimal and first infraorbital; maxillary barbel much shorter. Pharyngeal teeth in three rows: 5,4,2,2,4,5 (one specimen dissected).

Lateral line complete, comprising one tubed scale followed by a canal running steeply caudoventrad under five unperforated scales to slightly posterior to pectoral-fin base where canal curved caudad and represented by scales with indistinct or absent perforation anteriorly, but distinctly perforated posterior to adpressed pectoral fin; running in a curve parallel to the ventral body outline and ending low on caudal peduncle and caudal-fin base. About of caudal-fin length scaled basally. 


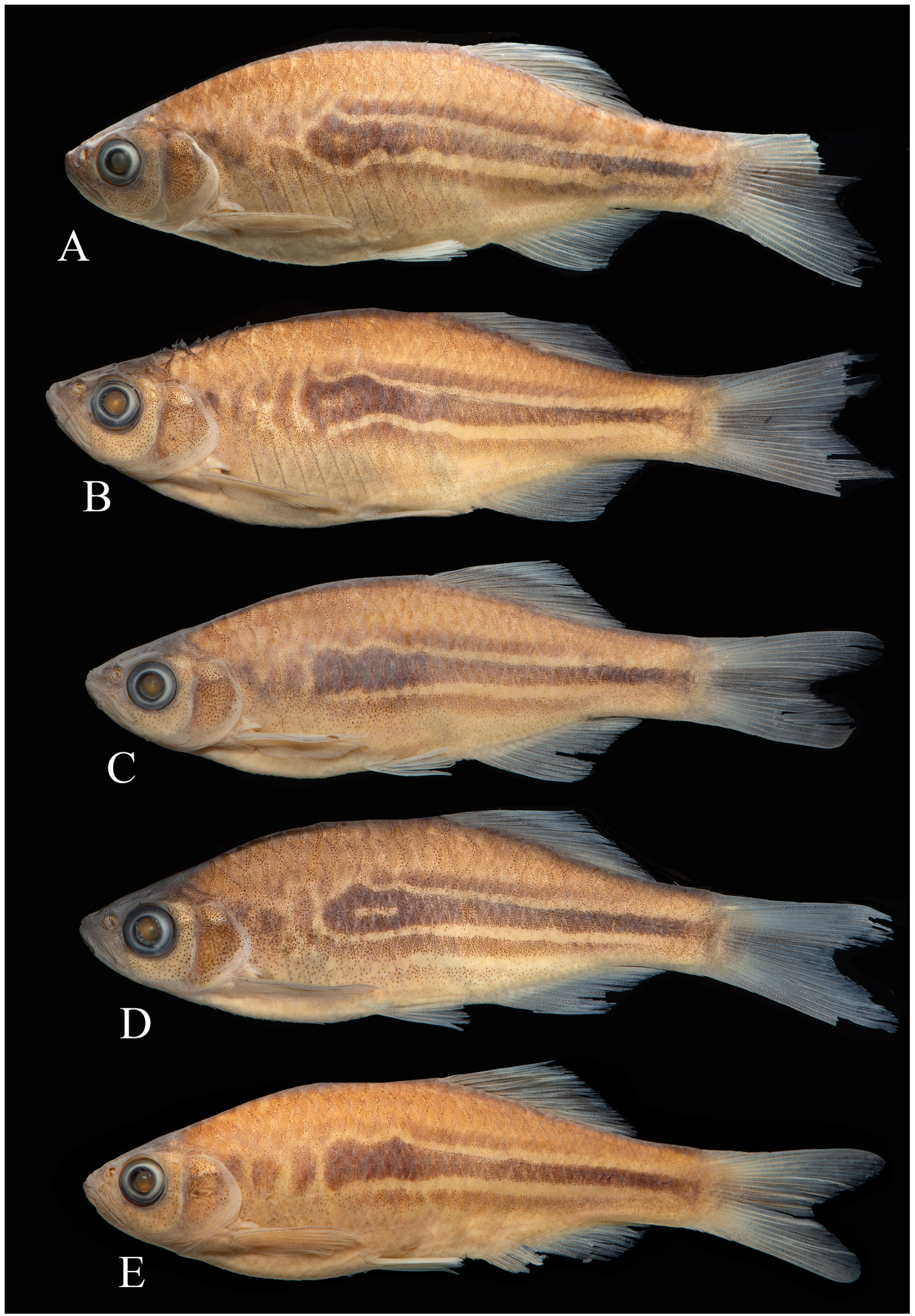

FIGURE 3. Devario browni. A, NRM 36393, adult male, $62.1 \mathrm{~mm} \mathrm{SL}$, reversed; B, adult female, $58.3 \mathrm{~mm}$ SL, reversed; C, young male, $44.9 \mathrm{~mm}$ SL, reversed; D, young male, $49.5 \mathrm{~mm} \mathrm{SL}$; E, NRM 36361, young male $49.7 \mathrm{~mm}$ SL. All from Myanmar, Shan State, Irrawaddy River basin, Lawe Pyat stream, on Road Lashio-Tigyaing. 
Dorsal fin inserted at highest point of dorsum, slightly posterior to middle of body. Anal fin inserted below anterior rays of dorsal fin. Pectoral-fin insertion at about vertical through posterior margin of osseous opercle; extending to pelvic-fin insertion. Pectoral axial lobe present. Pelvic fin inserted slightly anterior to midbody, not reaching to anal-fin insertion. Pelvic axillary scale present. Caudal fin forked, lobes of about equal length, tips rounded.

Colouration in preservative. Dorsum pale brown; dark brown mid-dorsal stripe from occiput to base of upper caudal-fin rays; lower sides, chest and abdomen pale yellowish white. Caudal peduncle ventrally yellowish white. Opercle silvery, powdered with brown; a brown patch dorsally. Vertically oriented brown cleithral spot covering part of first lateral-line scale and scale above.

Flank colour pattern varying with specimen size, and slightly on each side. Adults with dark brown P stripe along middle of side, narrow at end of caudal peduncle, irregular, gradually widening cephalad to about doubled width or more at abrupt anterior termination. Light spot anteriorly in $\mathrm{P}$ stripe present or absent. $\mathrm{P}+1$ narrower than $\mathrm{P}$ stripe, light brown, paralleling $\mathrm{P}$ stripe, running from caudal peduncle to anterior termination of $\mathrm{P}$ stripe.

P +2 stripe absent. P-1 stripe narrower than P stripe; irregular, greyish brown, well demarcated against I-1 stripe, fading ventrally; extending from end of caudal peduncle cephalad to about level of anterior termination of P stripe. Two or three brown vertical bars or ovoid blotches anterior to P stripe. Interstripes I +1 and I-1 joined anterior to termination of $\mathrm{P}$ stripe, or light interspace of vertical bar anterior to $\mathrm{P}$ stripe bridging ends of interstripes $\mathrm{I}+1$ and I-1.

Dorsal fin proximally pale grey, translucent; distal half diaphanous. Middle rays of caudal fin light grey, translucent, fading posteriorly on fin. Pectoral and pelvic fins white, translucent.

Juveniles about $25 \mathrm{~mm}$ similar to adults but interstripes not connected anteriorly; P stripe brown, distinct, relatively narrower than in adults. In specimens about $18 \mathrm{~mm}$, SL and shorter, horizontal stripes indistinct; P stripe represented by light brown pigmentation suffused on abdominal side.

Devario sp. cf. browni from Yunnan. Yunnan specimens inadequately preserved, overall brownish and most specimens with indistinct colour pattern (Fig. 5). Body proportions and meristic data similar to D. browni and $D$. ahlanderi, but specimens not in a good state of preservation.

Most specimens from the Nangun River with relatively narrow P stripe, only slightly widened anteriorly and terminating in a short vertical bar. Specimens from the Qingshui River (in the Nangun River basin) with large or small dark blotch terminating P stripe at level of pelvic fin insertion.

Geographical distribution and habitat. The type locality of Devario browni is not known, but was probably near Lashio in the upper Irrawaddy River basin. Specimens from streams near Lashio were identified as D. browni (Appendix 1). Presence of D. browni in the upper Salween River basin in Yunnan was not confirmed. Devario shanensis was syntopic with $D$. browni near Lashio (Appendix 1).Other syntopic fish species were identified as Opsarius barnoides, Pethia stoliczkana, and Danio roseus.

\section{Devario ahlanderi, new species}

Type series. Holotype, NRM 57999 (Fig. 4 A), adult female, 65.2 mm SL; Myanmar: Shan State: stream close to Naung Al Village, about 6 miles (9 km) east of Kak-ku, 2026'5'N, 9713'2'”E; Thein Win and Thein Tan, 13 March 2008. Paratypes listed in Appendix 1.

Definition. Distinguished from all other species of Devario by the modification in adults of the anterior half of the P stripe into a series of short irregular bars or spots.

Description of type series. Morphometric and meristic data are given in Appendix 2.

Body laterally compressed, elongate, sexes not significantly different in body depth, but sample small. Predorsal contour straight ascending or with minor indentation above orbit, dorsal contour sloping posterior to posterior dorsal-fin insertion. Prepelvic contour strongly curved, more so in females; chest conspicuously more compressed below pectoral fin, but not keeled. Snout short, rounded in dorsal aspect, subtriangular in lateral aspect, about as long as eye diameter. Infraorbital process broader than high, with truncate distal margin which usually slightly irregular, not projecting from skin. Danionine notch caudally margined by well-developed anteromediad projecting laminar dentary process. Skin cover absent from distal part of dentary process. Mouth terminal, directed obliquely upwards. Bony knob at dentary symphysis minor, fitting in shallow depression in upper jaw. Maxilla reaching to below anterior margin of orbit. Jaws equal anteriorly; lower jaw ending anteriorly at horizontal through middle of 
eye. Three specimens, $42.2-56.9 \mathrm{~mm}$ SL identified as adult males by presence of irregular band or two distinct rows of short tubercles along orad margin of dentary and presence of dense bands of sharp tubercles on pectoral-fin rays. Tubercles absent from lower jaw in holotype and remaining paratypes. Rostral barbel short, reaching to junction of lacrimal and first infraorbital; maxillary barbel much shorter.

Pharyngeal teeth in three rows: 5,42,2,4,5 (one specimen dissected).

Lateral line complete, along 31-34 scales; comprising one tubed scale followed by a canal running steeply caudoventrad under unperforated scales to slightly posterior to pectoral-fin base, where curved caudad and represented by scales with indistinct or absent perforation anteriorly, becoming distinctly perforated posterior to adpressed pectoral fin; running in a curve parallel to the ventral body outline and ending low on caudal peduncle and caudal-fin base; vertical section represented by about six scales. A row of scales covering anal-fin base. About $1 / 4$ of caudal-fin length scaled basally.

Dorsal fin inserted at highest point of dorsum, distinctly posterior to middle of body. Anal fin inserted below anterior rays of dorsal fin. Pectoral-fin insertion at about vertical through posterior margin of osseous opercle; extending to pelvic-fin insertion. Pectoral axial lobe well developed. Pelvic fin inserted slightly anterior to midbody, not reaching to anterior insertion of anal fin. Pelvic axillary scale present. Caudal fin forked, lobes of about equal length, tips rounded.

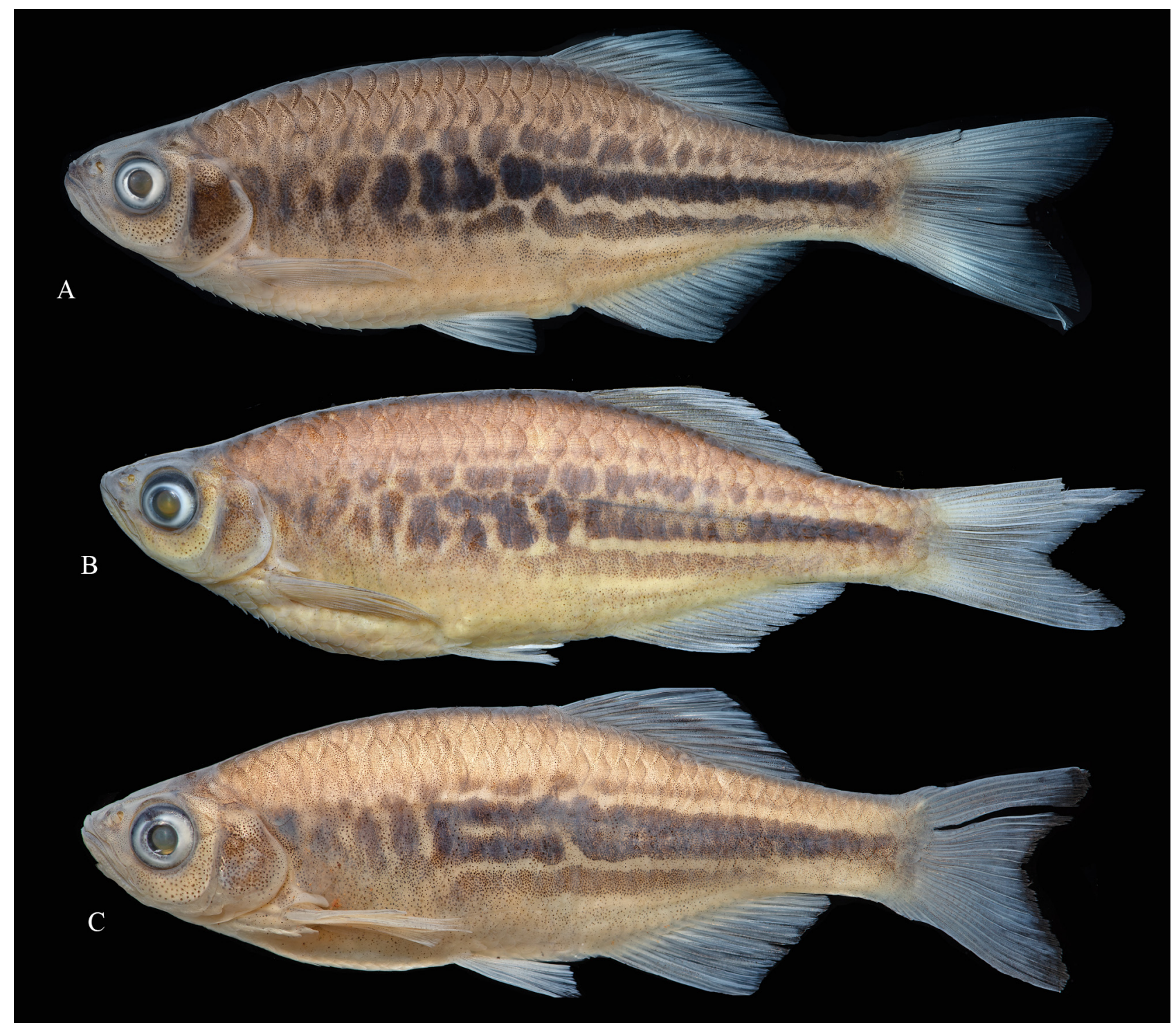

FIGURE 4. Devario ahlanderi. All from Myanmar, Shan State, Salween River basin. A, holotype, NRM 57999, adult female, 65.2 mm SL; stream close to Naung Al Village, about 6 miles (9 km) east of Kak-ku. B, paratype, NRM 58062, adult male, 56.9 mm SL, same locality as holotype; C, paratype, NRM 58061, adult female, 55.6 mm SL; small stream running under Naung Pic bridge near Naung Pic Village, on the way from Kak-ku to Taunggyi. 


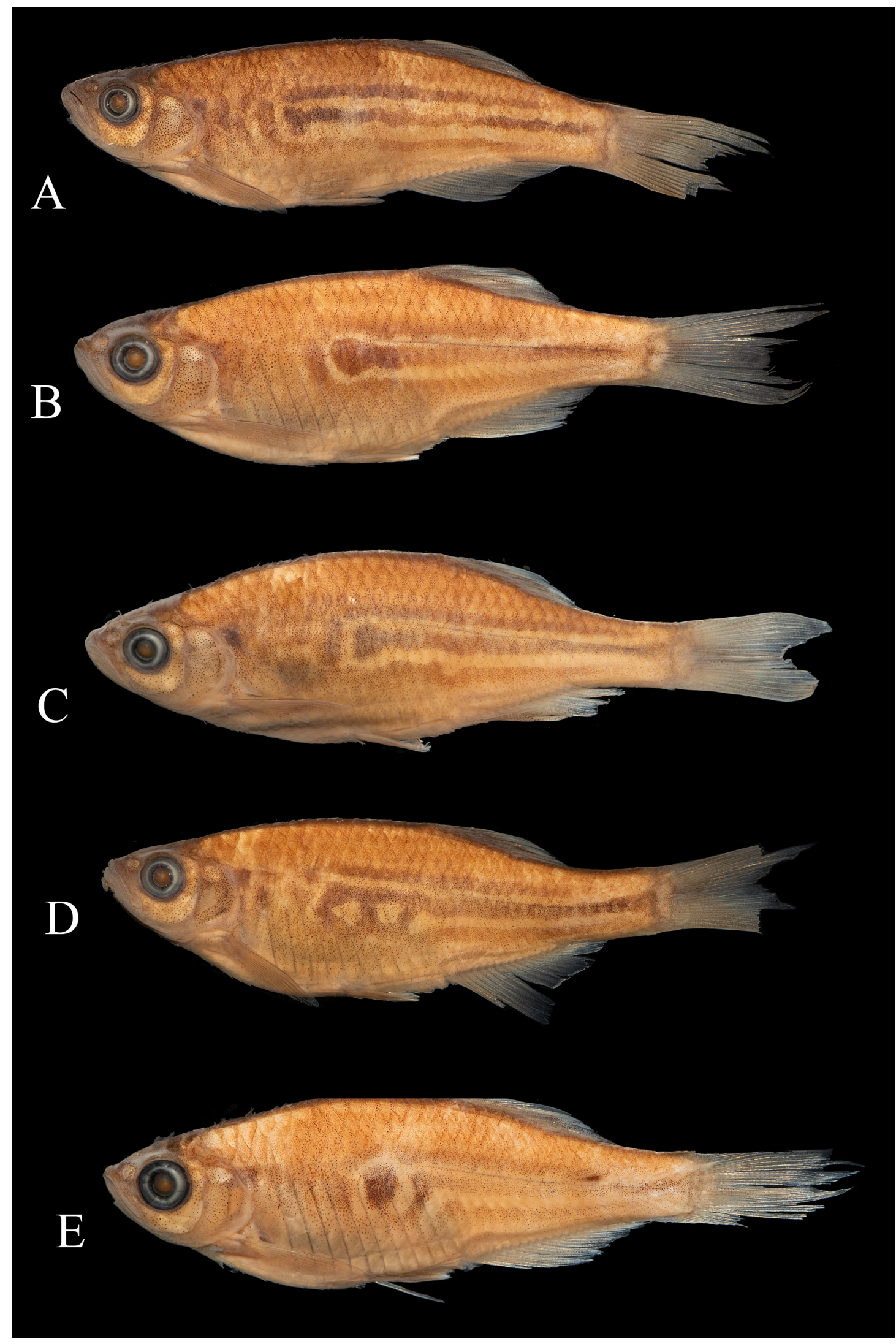

FIGURE 5. Devario cf. browni, all from P.R. China,Yunnan, Salween River basin. A, ZMUYU 874064, adult male, $60.5 \mathrm{~mm}$ SL: Canguyan County: Nangun River. B. ZMYU 80650, young female $42.1 \mathrm{~mm}$ SL; Gengma County: Qingshui River. C, ZMYU 80650, young female, 49.9 mm SL, right side, reversed: Gengma County: Qingshui River. D, ZMYU, young female, 50.0 mm SL; Canguyan County: Nangun River; E, ZMYU 80650, young female, 42.7 mm SL; Gengma County: Qingshui River. 
Colouration in preservative. Dorsum pale grey, dark grey line from occiput to base of upper caudal fin rays; sides off-white, chest and abdomen off-white or yellowish white depending on conservation. Opercle silvery, powdered with scattered melanophores; a brown patch dorsally. Dark brown vertically oriented cleithral spot covering part of first lateral-line scale and scale above.

Adult flank colour pattern (Fig. 4) varying with specimen size, and slightly on each side. Adults with black P stripe along middle of side from slight widening at end of caudal peduncle, running cephalad with irregular margins and increasing slightly in width anteroposteriorly; from about level of dorsal-fin anterior insertion replaced by black, irregularly shaped spots (rounded or as short vertical bars); anterior two spots much lighter and smaller than remainder. P-1 stripe narrower than P stripe; irregular, brown, extending from end of caudal peduncle cephalad to about vertical from anterior insertion of dorsal fin, where broken up in irregular spots paralleling or interdigitating with P stripe spots. P-2 stripe indistinct, grading into light abdomen. P +1 stripe extending from end of caudal peduncle, narrower than P stripe but wide medially and tapering in width at ends; consisting of brown blotches paralleling or interdigitating with P stripe blotches. Dorsal fin distally without pigment, basally light grey, translucent. Anal fin not pigmented. Middle rays of caudal fin light grey, fading posteriorly on fin. Pelvic fin white, translucent.

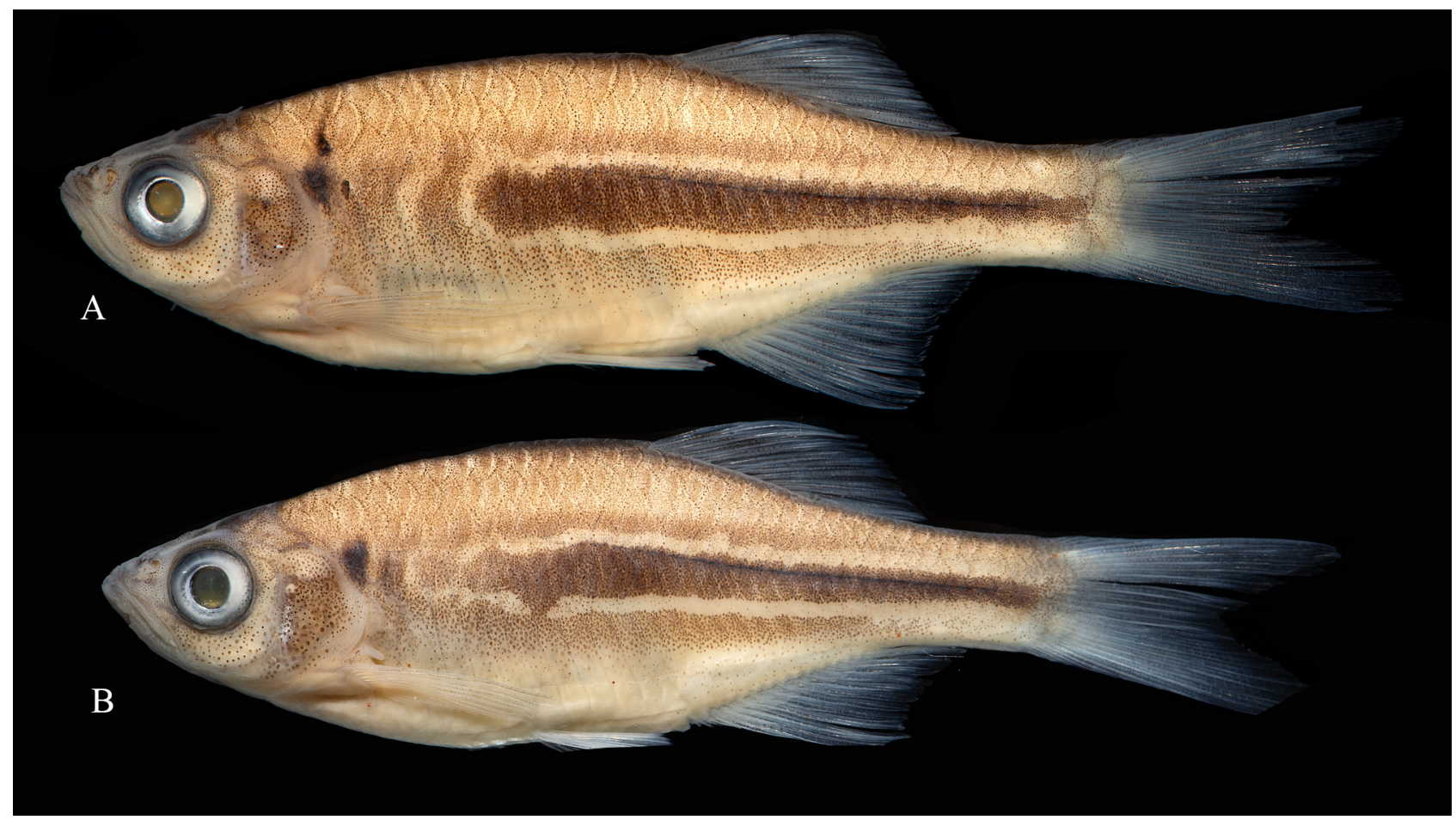

FIGURE 6. Devario ahlanderi, subadult paratypes. A, $42.0 \mathrm{~mm} \mathrm{SL}$; B, $36.9 \mathrm{~mm}$ SL; both from Myanmar, Shan State, small stream running under Naung Pic bridge near Naung Pic Village, on the way from Kak-ku to Taunggyi.

Juveniles similar to adults, but spotted pattern absent (Fig. 6). Smallest juveniles available $20 \mathrm{~mm}$, with pale brown mid-dorsal stripe, black line along middle of side, and suffused brown or grey pigmentation on lower flank. At about $30 \mathrm{~m} \mathrm{SL}$, wide brown P stripe, slightly increasing in width anteriorly, with contrasting marginal interstripes. At about $40 \mathrm{~mm}$ SL each specimen with unique colour pattern with irregular bars or small spots anteriorly in the P stripe, and the marginal stripes continuous or not in front of the P stripe.

Geographical distribution and habitat. Devario ahlanderi is known only from two small streams near Taunggyi (Figs 1). The type locality was a small shaded stream $100 \%$ shaded by bamboo trees. Devario jayarami was collected together with D. ahlanderi, and Devario sondhii was available in the Taunggyi market together with $D$. ahlanderi (Appendix 1). Other syntopic species were identified as Lepidocephalichthys berdmorei, Pethia stoliczkana, Danio margaritatus, and Trichogaster trichopterus.

Explanation of the specific name: The specific name is a noun in the genitive case. The species is dedicated to Erik Åhlander, long time Senior Assistant in the ichthtyology and herpetology collection of the Swedish Museum of Natural History, and a key person in the successful development and operation of ichthyology at the NRM. 


\section{Discussion}

The specimens of Devario from Yunnan reported here, were first reported by Fang (2000) who identified them as Devario browni. Fang also referred to D. browni records of D. aequipinnatus from Mengding County (Chu 1981) and Menglai County (Kuang 1989), both places on the Nanting River, also a headwater of the Salween River in Yunnan.

Kuang's (1989) illustration of Devario aequipinnatus shows a colour pattern similar to that of $D$. browni, particularly the light area on the anterior portion of the P stripe. There were no other localities reported of D. browni as a valid species in P.R. China or the Salween River basin. The Chinese localities are close to headwaters of the Irrawaddy River basin, and cross-basin distribution following stream capture seems plausible. Available collections are small and random, and do not permit a biogeographic analysis. The poor condition of the Yunnan specimens, and the difference in colour pattern does not allow identification of these specimens as D. browni. In this context, however, it is noteworthy that Devario shanensis, sympatric with D. browni in the Irrawaddy River basin, was reported from the middle Salween River in P.R. China by Yang and Huang (1964), and from the upper Salween River in Gazhong, Luxi County (now Mangshi), Yunnan, by Chu (1981). Fang (2000) expressed doubts about the identification based on data in the descriptions, and the accuracy of the image by Yang and Huang (1964: 16). The latter was reproduced as Devario interruptus (Day, 1870) by Chu (1989; fig. 8), a species otherwise only known from the Irrawaddy River basin in P.R. China. Fang (2000) labelled the Chinese records of D. shanensis as Danio cf. shanensis. There are no further published records of putative Devario shanensis from the Salween River basin but a specimen identified as a putative D. shanensis, NRM 32200, was available from the Nan Bang He River, a headwater of the Salween River in Yunnan, about $200 \mathrm{~km}$ north of Lashio.

Hora and Mukerji's (1934) descriptions of Devario aequipinnatus from Kyoksu, a village west of Ho Pong, and near Lawksawk, slightly north of Taunggyi, mention irregular horizontal stripes, and may refer to Devario ahlanderi.

Spotted species of Devario have occurred in the ornamental fish hobby. Cottle (2010: 64) reported Devario sp. Giraffe, with an illustration showing a specimen with dark vertical bars anteriorly on the side, small dark blotches in the $\mathrm{P}+1$ stripe, and posteriorly narrow $\mathrm{P}$ and $\mathrm{P}-1$ stripes made up of more or less contiguous spots; dark markings margined with pink. The locality was given as Ban Mae Sam Laep on the lower Salween River in Thailand. Cottle (2010: 73) also figured a specimen identified as Devario cf. malabaricus, but stated to be from Myanmar and with a colour pattern similar to $D$. ahlanderi.

Because of the similarity in colour pattern, it was relevant to include Devario kysonensis in the comparison with D. ahlanderi. The unique ontogenetic transformation of the colour pattern in D. kysonensis, however, raises concern about the homology of the similar, but not identical spotted colour pattern in adult $D$. ahlanderi, and it is noted here only as an example of evolutionary similarity.

The majority of species of Devario is characterised by a gradual ontogenetic change of the colour pattern, from a narrow P stripe to adult species-specific patterns of blotches, bars, or stripes anteriorly on the flank. Rare exceptions include Devario sondhii with plain sides. Devario ahlanderi and D. kysonensis introduce another category of melanic colour pattern in the genus, but still compatible with the numerical scheme introduced in 1997 (Fang 1997, 1998), enabling homology assessment of the colour pattern components in the genus. Fang distinguished between striped devarios, referring to the predominantly anteroposterior striped colour pattern and barred devarios characterised by presence of short vertical bars along the flank. Devario ahlanderi and D. kysonensis combine bars and stripes but nonetheless represent striped devarios, evident not least in the subadult and juvenile colour pattern and markers such as presence of the infraorbital process (Fang 2001; Kottelat 2020). Fragmentation of the anterior portion of the P stripe is common among striped devarios, e.g. Devario anomalus (Kullander et al. 2017), D. deruptotalea Ramananda and Vishwanath, 2014 (Ramananda and Vishwanath 2014), D. gibber Kottelat, 2000 (cf. Kottelat 2000), and most species in Sri Lanka (cf. Sudasinghe et al. 2020). The pigmentation of this region of the body may be under strong selection in a genus very conservative in other characters used in taxonomic descriptions.

Small samples dominated by small juveniles, market specimens, and strongly curved specimens prevented a thorough morphometric analysis. The absence of discriminating characters in the available data is not surprising, however. Most fish species descriptions use ratios as morphological characters, and comparison with recently published such data (Kottelat 2020; Kullander, 2017) shows absence of discriminating characters in records of proportional measurements among species of striped Devario. Another weakness in our analysis is that colour pat- 
tern in the present group of Devario is ontogenetically variable and specimen specific. Our largest specimens of $D$. ahlanderi were below the size when the pattern of large spots changes to dispersed small spots in D. kysonensis. Figure $4 \mathrm{C}$ shows a specimen of $D$. ahlanderi approaching the predominant pattern in $D$. browni, with an expanded anterior $\mathrm{P}$ stripe enclosing a light centre.

The significance of the two species in focus here lies in expanding of the group of species characterised by a particular light lining of the $\mathrm{P}$ stripe, combined with irregular bars or blotches anteriorly in the $\mathrm{P}$ stripe. (Devario ahlanderi, D. browni, D. fangae, ) and/or relationship derived from DNA sequences (D. ahlanderi, D. fangae, D. kakhienensis). As far as known, these represent a sequence of discrete localities from the upper Irrawaddy River basin to the mid-lower Salween River basin in Myanmar, and possibly further present in the lower Mekong and Song Lam River. So far species of striped Devario have been considered endemic to single river basins and each characterised by unique colour pattern, but the present study and recent work by Kottelat $(2020,2021)$ suggest that both cross-basin distribution and parallelism in colour pattern are factors that may inspire more research into the biogeography and taxonomy of this genus.

\section{Acknowledgements}

Unpublished notes and photographs by Fang Fang (1962-2010), facilitated data recording. Specimen loans were patiently extended by the Natural History Museum, London. During the pandemic lockdown. James Maclaine checked statements referring to the BMNH fish collection. Maurice Kottelat, Ralf Britz, and an anonymous reviewer read the manuscript and contributed improvements Bo Delling, NRM made digital X-radiographs.

\section{References}

Barman, R.P. (1991) A taxonomic revision of the Indo-Burmese species of Danio Hamilton Buchanan (Pisces: Cyprinidae). Records of the Zoological Survey of India. Occasional Paper, 137, 1-91.

Chaudhuri, B.L. (1911) Contributions to the fauna of Yunnan based on collections made by J. Coggin Brown, B.Sc., 1909-1910. Part II. Fishes. Records of the Indian Museum, 6 (1), 13-24.

Chu, X.-L. (1981) A preliminary revision of fishes of the genus Danio from China. Zoological Research, 2 (2), 145-156. [in Chinese]

Conway, K.W., Mayden, R.L. \& Tang, K.L. (2009 Devario anomalus, a new species of freshwater fish from Bangladesh. Zootaxa, $2136(1), 49-58$. https://doi.org/10.11646/zootaxa.2136.1.4

Cottle, P.W. (2010) Danios and Devarios. Peter W. Cottle, Rochester, vii + 124 pp.

Fang, F. (1997) Redescription of Danio kakhienensis, a poorly known cyprinid fish from the Irrawaddy basin. Ichthyological Exploration of Freshwaters, 7, 289-298.

Fang, F. (1998) Danio kyathit, a new species of cyprinid fish from Myitkyina, northern Myanmar. Ichthyological Exploration of Freshwaters, 8, 273-280.

Fang, F. (2000) A review of Chinese Danio species (Teleostei: Cyprinidae). Acta Zootaxonomica Sinica, 25, $214-227$.

Fang, F. \& Kottelat, M. (1999) Danio species from northern Laos, with descriptions of three new species (Teleostei: Cyprinidae). Ichthyological Exploration of Freshwaters, 10, 281-295.

Fang, F. \& Kullander, S.O. (2009) Devario xyrops, a new species of danionine fish from south-western Myanmar (Teleostei: Cyprinidae). Zootaxa, 2164 (1), 33-40. https://doi.org/10.11646/zootaxa.2164.1.3

Hora, S.L. (1929) Notes on fishes in the Indian Museum XVII. Loaches of the genus Nemachilus from Burma. Records of the Indian Museum, 31 (4), 311-334.

Hora, S.L. \& Mukerji, D.D (1934) Notes on fishes in the Indian Museum. XII. On a collection of fish from the S. Shan States and the Pegu Yomas, Burma. Records of the Indian Museum, 36, 123-138.

International Commission on Zoological Nomenclature (1999) International Code of Zoological Nomenclature. Fourth Edition. International Trust for Zoological Nomenclature, London, xxix $+306 \mathrm{pp}$.

Kottelat, M. (2000) Notes on the taxonomy, nomenclature and distribution of some fishes of Laos. Journal of South Asian Natural History, 5, 83-90.

Kottelat, M. (2012) Conspectus cobitidum, an inventory of the loaches of the world (Teleostei: Cypriniformes: Cobitoidei). Raffles Bulletin of Zoology, Supplement 26, 1-199.

Kottelat, M. (2013) The fishes of the inland waters of Southeast Asia: a catalogue and core bibliography of the fishes known to occur in freshwaters, mangroves and estuaries. Raffles Bulletin of Zoology, Supplement 27, 1-663. 
Kottelat, M. (2020) Redescription of Devario kysonensis and first record from Laos (Teleostei: Cyprinidae). Raffles Bulletin of Zoology, 68, 556-561. https://doi.org/10.26107/RBZ-2020-0071

Kottelat, M. (2021) Devario pullatus and D. subviridis, two new species of minnows from Laos (Teleostei; Cyprinidae). Ichthyological Exploration of Freshwaters, 30, 271-288. https://doi.org/10.23788/IEF-1143

Kuang, P. (1989). Danioninae. In: Chu, X. \& Chen,Y. (Eds.), The fishes of Yunnan, China. Part I. Cyprinidae. Science Press, Beijing, pp. 11-36. [in Chinese]

Kullander, F.F. (2001) Phylogeny and species diversity of the South and Southeast Asian cyprinid genus Danio Hamilton (Teleostei, Cyprinidae). Department of Zoology, Stockholm University, Stockholm, 26 pp. [PhD dissertation]

Kullander, S.O. (2017) Devario fangae and Devario myitkyinae, two new species of danionin cyprinids from northern Myanmar (Teleostei: Cyprinidae: Danioninae). Zootaxa, 4227 (3), 407-421. https://doi.org/10.11646/zootaxa.4227.3.7

Kullander, S.O., Rahman, M.M., Norén, M. \& Mollah, A.R. (2017) Devario in Bangladesh: Species diversity, sibling species, and introgression within danionin cyprinids (Teleostei: Cyprinidae: Danioninae). PloS ONE, 12 (11), e0186895. https://doi.org/10.1371/journal.pone.0186895

Menon, A.K.G. \& Yazdani, G.M. (1963) Catalogue of type-specimens in the Zoological Survey of India. Part 2-Fishes. Records of the Zoological Survey of India, 61 (1-2), 91-190.

Mukerji, D.D. (1934) Report on Burmese fishes collected by L.T.Col. R.W. Burton from the tributary streams of the Mali Hka River of the Myitkyina District (Upper Burma), Part II. Journal of the Bombay Natural History Society, 36, 39-80.

Northern Mine Research Society. (1963) Obituaries of members of the Institution of Mining and Metallurgy. Available from https://www.nmrs.org.uk/resources/obituaries-of-members/b/john-coggin-brown/_(accessed 26 May 2021)

Pramod, P.K., Fang, F., Rema Devi, K., Liao, T.Y., Indra, T.J., Jameela Beevi, K.S. \& Kullander, S.O. (2010) Betadevario ramachandrani, a new danionine genus and species from the Western Ghats of India (Teleostei: Cyprinidae: Danioninae). Zootaxa, 2519 (1), 31-47.

https://doi.org/10.11646/zootaxa.2519.1.2

Regan, C.T. (1907) Description of a new cyprinid fish of the genus Danio from Upper Burma. Records of the Indian Museum, $4,395$.

Sudasinghe, H., Pethiyagoda, R. \& Meegaskumbura, M. (2020) Evolution of Sri Lanka's Giant Danios (Teleostei: Cyprinidae: Devario): Teasing apart species in a recent diversification. Molecular Phylogenetics and Evolution, 106853, 1-15. https://doi.org/10.1016/j.ympev.2020.106853

Systat. (2009) Systat. Version 13. Systat software, San Jose. [program]

Tang, K.L., Agnew, M.K., Hirt, V., Sado, T., Schneider, L.M., Freyhof, J., Sulaiman, Z., Swartz, E., Vidthayanon, C., Miya, M., Saitoh, K., Simons, A.M., Wood, R.M. \& Mayden, R.L. (2010) Systematics of the subfamily Danioninae (Teleostei: Cypriniformes: (Cyprinidae). Molecular Phylogenetics and Evolution, 57, 189-214. https://doi.org/10.1016/j.ympev.2010.05.021

Yang, G.R. \& Huang, H.J. (1964) The Leuciscinae. In: Wu, H. (Ed.), The cyprinid fishes of China. Vol. 1. Technical Printing House, Shanghai, pp.1-61. [in Chinese] 
Appendix 1 Specimens examined

\begin{tabular}{|c|c|c|c|c|c|c|c|}
\hline ScientificName & Repository & Cat No & Type_status & $\mathbf{N}$ & SL (mm) & Storage & Locality \\
\hline D.browni & BMNH & 1907.10 .22 .14 & Lectotype & 1 & 57.0 & Ethanol & 1 \\
\hline D.browni & BMNH & 1907.10 .22 .14 & Paralectotypes & 4 & $18.6-525$ & Ethanol & 1 \\
\hline D. browni & ZSI & F872/1 & Paralectotypes & 5 & $16.4-50.5$ & Ethanol & 1 \\
\hline D. Cf. browni & ZMYU & 874085 & - & 1 & 51.3 & Ethanol & 2 \\
\hline D. cf. browni & ZMYU & $806501-05$ & - & 5 & $34.6-52.2$ & Ethanol & 3 \\
\hline D. cf. browni & ZMYU & $879002-5$ & - & 4 & $44.3-51.3$ & Ethanol & 2 \\
\hline D. cf. browni & ZMYU & 87404060 & - & 1 & 54.6 & Ethanol & 2 \\
\hline D. cf. browni & ZMYU & 87404064 & - & 1 & 60.5 & Ethanol & 2 \\
\hline D. cf. browni & ZMYU & - & - & 2 & $46.4-52.9$ & Ethanol & 2 \\
\hline D. cf. browni & ZMYU & 874094 & - & 1 & 48.6 & Ethanol & 2 \\
\hline D.browni & NRM & 36360 & - & 1 & 31.0 & Ethanol & 4 \\
\hline D.browni & NRM & 36361 & - & 4 & $38.2-49.7$ & Ethanol & 5 \\
\hline D.browni & NRM & 36264 & - & 31 & Jjuveniles & Ethanol & 5 \\
\hline D.browni & NRM & 36393 & - & 18 & $12.8-58.3$ & Ethanol & 5 \\
\hline D.browni & NRM & 36398 & - & 39 & $21.7-50.8$ & Ethanol & 5 \\
\hline D.shanensis & NRM & 37242 & - & 5 & NM & Ethanol & 5 \\
\hline D.shanensis & NRM & 37243 & - & 3 & NM & Ethanol & 5 \\
\hline D.shanensis & NRM & 37293 & - & 1 & NM & Ethanol & 5 \\
\hline D.shanensis & NRM & 37294 & - & 1 & NM & Ethanol & 5 \\
\hline D.shanensis & NRM & 49341 & - & 1 & NM & Ethanol & 5 \\
\hline D. cf. shanensis & NRM & 32200 & - & 1 & NM & Ethanol & 6 \\
\hline Devario $s p$. & NRM & 42640 & - & 12 & NM & Ethanol & 5 \\
\hline D.ahlanderi & NRM & 58074 & Paratype & 2 & $150-17.0$ & Ethanol & 7 \\
\hline D.ahlanderi & NRM & 58097 & Paratype & 4 & $20.3-23.4$ & Ethanol & 7 \\
\hline D.ahlanderi & NRM & 57999 & Holotype & 1 & 65.2 & Ethanol & 7 \\
\hline D.ahlanderi & NRM & 58062 & Paratype & 1 & 56.9 & Ethanol & 7 \\
\hline D.ahlanderi & NRM & 58527 & Paratype & 1 & Juvenile & Ethanol 95\% & 7 \\
\hline D.ahlanderi & NRM & 58528 & Paratype & 1 & juvenile & Ethanol 95\% & 7 \\
\hline D.ahlanderi & NRM & 58623 & Paratype & 1 & juvenile & Ethanol 95\% & 8 \\
\hline D.ahlanderi & NRM & 58624 & Paratype & 1 & Juvenile & Ethanol 95\% & 8 \\
\hline D.ahlanderi & NRM & 58061 & Paratype & 10 & $29.1 .9-55.6$ & Ethanol & 8 \\
\hline D.ahlanderi & NRM & 58521 & Paratype & 1 & Juvenile & Ethanol 95\% & 8 \\
\hline D.ahlanderi & NRM & 58524 & Paratype & 1 & Juvenile & Ethanol 95\% & 8 \\
\hline D.ahlanderi & NRM & 70997 & Paratype & 20 & Juvenile & Ethanol & 8 \\
\hline D.ahlanderi & NRM & 70998 & Paratype & 33 & Juvenile & Ethanol & 8 \\
\hline D.ahlanderi & NRM & 58211 & Paratype & 6 & $40.5-62.0$ & Ethanol & 9 \\
\hline D.ahlanderi & NRM & 58213 & Paratype & 6 & $34.4-59.2$ & Ethanol & 9 \\
\hline D.ahlanderi & NRM & 58276 & Paratype & 1 & 26.0 & Ethanol & 9 \\
\hline D.ahlanderi & NRM & 36264 & Paratypes & 31 & Juveniles & Ethanol & 9 \\
\hline D. sondhii & NRM & 58282 & - & 1 & NM & Ethanol & 9 \\
\hline D. jayarami & NRM & 58082 & - & 14 & NM & Ethanol & 10 \\
\hline D. jayarami & NRM & 58630 & - & 1 & NM & Ethanol 95\% & 10 \\
\hline D. jayarami & NRM & 58631 & - & 1 & NM & Ethanol $95 \%$ & 10 \\
\hline D. jayarami & NRM & 58632 & - & 1 & NM & Ethanol $95 \%$ & 10 \\
\hline
\end{tabular}




\section{Locality metadata}

1. Irrawaddy River basin: Myanmar: Northern Shan States: J. Coggin Brown, 1907.

2. Salween River basin: P.R. China: Yunnan: Canguyan County:a Nangun He River, about 23.145992, $99.113708^{\circ}$; collector and date not recorded.

3. P.R. China: Yunnan: Gengma County: Qingshui He River, about 23.516165 $99.140166^{\circ}$; collector and date not recorded.

4. Irrawaddy River basin: Myanmar: Shan State: small stream at Naungkwe village, about 48 km on road HsipawLashio, 22.74833 ,97.61945 ; F. Fang and A. Roos, 24 Mar 1997.

5. Irrawaddy River basin: Myanmar: Shan State: Lawe Pyat Stream at Hong Lic village, about $26 \mathrm{~km}$ on road LashioTigyaing; $23^{\circ}, 13305^{\circ}, 97.84361^{\circ}$; F. Fang et al., 26 Mar 1997.

6. Salween River basin: P.R. China: Yunnan: Zhen Kang County:Nan Bang He River, tributary to Nan Ding He River,

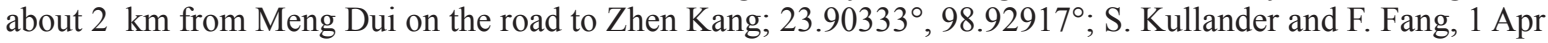
1995.

7. Salween River basin: Myanmar: Shan State: Taunggyi: Taunggyi Township; stream close to Naung Al Village, about 6 miles (9 km) east of Kak-ku, 20.43464 , 97.21732; F. Fang et al., 13 Mar 2008.

8. Salween River basin: Myanmar: Shan State: Taunggyi: Taunggyi Township: small stream running under Naung Pic bridge near Naung Pic Village, on the way from Kakku to T aunggyi; 20.58515²,97.06207 ; B. delling et al., 13 Mar 2008.

9. Salween River basin: Myanmar: Shan State: Taunggyi: Taunggyi Township: Taunggyi open air market: $20.78188^{\circ}$, 97.03788 ; F. Fang et al., 14 Mar 2008.

10. Salween River basin: Myanmar: Shan State: Taunggyi: Taunggyi Township: Stream close to Naung Al Village, about 6 miles $(9 \mathrm{~km})$ east of Kak-ku, 20.43464 ${ }^{\circ}$ 97.21732; F. Fang et al., 13 Mar 2008.

Appendix 2. Morphometric and meristic data of Devario ahlanderi, D. browni, and Devario cf. browni.

Table 1. Devario browni: Size range (mm), proportional measurements (\% of SL), correlation (Pearson's r). regression parameters slope (a), intercept (b). Linear regression $\mathrm{p}=0.000$

\begin{tabular}{lccccccccc}
\hline & Lectotype & $\mathrm{N}$ & Min & Max & Mean & SD & r & a & b \\
\hline SL & 57.0 & 13 & 38.2 & 62.1 & 48.5 & 7.4 & & & 0.329 \\
Body depth & 34.2 & 13 & 28.0 & 34.2 & 30.4 & 1.7 & 0.9 & -1.178 & -0.678 \\
Head length & 25.6 & 13 & 23.8 & 29.0 & 26.2 & 1.2 & 1.0 & 0.276 \\
Snout length & 7.5 & 13 & 7.0 & 8.4 & 7.5 & 0.4 & 1.0 & -0.722 & 0.090 \\
Head depth & 19.6 & 13 & 14.4 & 19.6 & 16.2 & 1.6 & 0.9 & -2.180 & 0.222 \\
Head width & 14.4 & 13 & 13.1 & 14.9 & 13.9 & 0.6 & 1.0 & 0.140 & 0.139 \\
Upper jaw length & 10.7 & 13 & 9.6 & 11.5 & 10.5 & 0.7 & 0.9 & 1.096 & 0.082 \\
Lower jaw length & 12.5 & 13 & 12.0 & 14.6 & 13.1 & 0.7 & 1.0 & -0.135 & 0.134 \\
Orbital diameter & 7.9 & 13 & 7.9 & 9.4 & 8.6 & 0.4 & 1.0 & 0.883 & 0.068 \\
Interorbital width & 11.2 & 13 & 10.2 & 11.9 & 11.2 & 0.4 & 1.0 & 0.282 & 0.106 \\
Caudal peduncle length & 17.5 & 13 & 16.1 & 21.1 & 17.9 & 1.3 & 0.9 & -0.963 & 0.199 \\
Caudal peduncle depth & 13.2 & 13 & 11.5 & 13.3 & 12.3 & 0.6 & 0.9 & 0.417 & 0.114 \\
Dorsal-fin base length & 19.6 & 13 & 17.8 & 21.7 & 19.4 & 1.3 & 0.9 & 2.137 & 0.149 \\
Anal-fin base length & 17.2 & 13 & 17.1 & 21.4 & 19.2 & 1.4 & 0.9 & 2.631 & 0.136 \\
Predorsal length & 58.6 & 13 & 57.9 & 63.1 & 59.4 & 1.4 & 1.0 & -2.329 & 0.463 \\
Preanal length & 64.6 & 13 & 59.9 & 69.1 & 64.6 & 2.4 & 1.0 & -2.199 & 0.707 \\
Prepelvic length & 51.1 & 13 & 45.9 & 51.8 & 48.1 & 1.9 & 1.0 & -1.667 & 0.516 \\
Pectoral-fin length & 20.4 & 13 & 20.4 & 24.7 & 22.5 & 1.2 & 0.9 & 1.013 & 0.204 \\
Pelvic-fin length & 14.9 & 13 & 14.1 & 17.1 & 15.6 & 0.8 & 1.0 & \\
\hline
\end{tabular}


Table 2. Devario ahlanderi. Proportional measurements (\% of SL), size range (mm), Pearson's r, linear regression on SL (a, slope, $b$, intercept). Linear regression $p=0.000$.

\begin{tabular}{lccccccccc}
\hline & Holotype & $\mathrm{N}$ & Min & Max & Mean & SD & r & a & b \\
\hline SL & 65.2 & 13 & 28.6 & 65.2 & 46.6 & 10.8 & & & \\
Body depth & 31.9 & 13 & 27.4 & 31.9 & 29.0 & 1.2 & 1.00 & -2.047 & 0.036 \\
Head length & 23.8 & 13 & 23.4 & 29.0 & 25.8 & 1.8 & 0.99 & -2.871 & 0.193 \\
Snout length & 7.1 & 13 & 4.2 & 7.9 & 6.8 & 0.9 & 0.98 & -2.090 & 0.073 \\
Head depth & 17.2 & 13 & 13.8 & 19.6 & 16.5 & 1.8 & 0.93 & 0.475 & 0.154 \\
Head width & 13.2 & 13 & 12.7 & 14.3 & 13.3 & 0.5 & 0.99 & 0.184 & 0.089 \\
Upper jaw length & 9.5 & 13 & 9.5 & 11.2 & 10.0 & 0.5 & 0.99 & 1.990 & 0.086 \\
Lower jaw length & 12.0 & 13 & 11.6 & 17.5 & 13.1 & 1.5 & 0.95 & 1.990 & 0.086 \\
Orbital diameter & 7.4 & 13 & 7.4 & 10.5 & 8.9 & 0.9 & 0.99 & 1.770 & 0.500 \\
Interorbital width & 10.3 & 13 & 9.7 & 11.9 & 10.9 & 0.6 & 0.98 & 0.621 & 0.095 \\
Caudal peduncle length & 18.3 & 13 & 17.4 & 21.5 & 19.4 & 1.3 & 0.98 & 0.966 & 0.172 \\
Caudal peduncle depth & 12.0 & 13 & 10.2 & 12.2 & 11.2 & 0.7 & 1.00 & -1.130 & 0.137 \\
Dorsal-fin base length & 18.7 & 13 & 15.5 & 20.1 & 17.8 & 1.2 & 1.00 & -0.457 & 0.189 \\
Anal-fin base length & 21.0 & 13 & 18.7 & 21.7 & 20.3 & 1.0 & 0.99 & -1.060 & 0.226 \\
Predorsal length & 59.4 & 13 & 56.0 & 61.1 & 58.3 & 1.5 & 0.99 & -0.220 & 0.587 \\
Preanal length & 65.0 & 13 & 62.2 & 67.3 & 64.1 & 1.6 & 1.00 & -1.278 & 0.069 \\
Prepelvic length & 46.0 & 13 & 46.0 & 49.6 & 47.5 & 1.2 & 0.99 & 0.759 & 0.016 \\
Pectoral-fin length & 21.5 & 13 & 21.5 & 26.2 & 24.0 & 1.4 & 0.99 & 1.565 & 0.205 \\
Pelvic-fin length & 15.5 & 13 & 14.8 & 19.6 & 16.6 & 1.2 & 0.97 & 0.966 & 0.144 \\
\hline
\end{tabular}

Table 3. Devario. cf. browni fromYunnan. Proportional measurements (\% of SL), size range (mm).

\begin{tabular}{lrrrrrr}
\hline \multicolumn{1}{c}{ SL } & N & Min & Max & Mean & SD & r \\
\hline SL & 16 & 34.6 & 60.5 & 48.2 & 6.1 & \\
Body depth & 16 & 26.0 & 33.0 & 29.0 & 2.1 & 0.8 \\
Head length & 16 & 23.6 & 26.7 & 24.8 & 1.1 & 1.0 \\
Snout length & 16 & 5.0 & 7.2 & 6.4 & 0.7 & 0.8 \\
Head depth & 16 & 14.8 & 16.8 & 15.9 & 0.6 & 1.0 \\
Head width & 16 & 12.4 & 14.0 & 13.3 & 0.6 & 0.9 \\
Upper jaw length & 16 & 8.8 & 10.5 & 9.5 & 0.6 & 0.9 \\
Lower jaw length & 16 & 10.1 & 13.4 & 12.4 & 0.8 & 0.9 \\
Orbital diameter & 16 & 8.1 & 9.8 & 8.9 & 0.5 & 0.9 \\
Interorbital width & 16 & 9.4 & 12.4 & 10.5 & 0.7 & 0.9 \\
Caudal peduncle length & 16 & 15.7 & 23.6 & 18.7 & 2.4 & 0.7 \\
Caudal peduncle depth & 16 & 10.1 & 12.9 & 11.3 & 0.8 & 0.8 \\
Dorsal-fin base length & 16 & 16.0 & 22.2 & 18.2 & 1.5 & 0.8 \\
Anal-fin base length & 16 & 20.5 & 26.7 & 22.5 & 1.7 & 0.8 \\
Predorsal length & 16 & 51.5 & 63.9 & 57.1 & 2.5 & 1.0 \\
Preanal length & 16 & 55.3 & 67.9 & 61.5 & 3.0 & 0.9 \\
Prepelvic length & 16 & 42.3 & 50.9 & 46.5 & 2.4 & 0.9 \\
Pectoral-fin length & 16 & 19.9 & 24.9 & 22.5 & 1.4 & 0.9 \\
Pelvic-fin length & 16 & 13.1 & 16.5 & 15.0 & 1.0 & 0.9 \\
\hline
\end{tabular}


Table 4. ANCOVA of linear regression on SL in Devario browni and D. ahlanderi samples N=13+13. Slope same at $\mathrm{p}>0.05$; intercept different at $\mathrm{p}<0.05$.

\begin{tabular}{lcccc} 
& & Slope & \multicolumn{2}{c}{ Intercept } \\
\cline { 1 - 4 } Body depth & F-ratio & $\mathrm{p}$ & F-ratio & $\mathrm{p}$ \\
Head length & 3.790 & 0.843 & 3.79 & 0.064 \\
Snout length & 11.797 & 0.002 & Void & Void \\
Head depth & 1.884 & 0.184 & 6.951 & 0.15 \\
Head width & 3.054 & 0.095 & 0.048 & 0.828 \\
Upper jaw length & 0.697 & 0.413 & 9.967 & 0.005 \\
Lower jaw length & 0.409 & 0.529 & 6.515 & 0.018 \\
Orbital diameter & 9.907 & 0.005 & Void & Void \\
Interorbital width & 7.15 & 0.014 & 0.042 & 0.839 \\
Caudal peduncle length & 1.042 & 0.318 & 5.313 & 0.031 \\
Caudal peduncle depth & 0.825 & 0.374 & 6.171 & 0.021 \\
Dorsal-fin base length & 3.64 & 0.700 & 19.212 & 0.000 \\
Anal-fin base length & 2.364 & 0.139 & 10.409 & 0.004 \\
Predorsal length & 14.516 & 0.001 & Void & Void \\
Preanal length & 2.638 & 0.119 & 3.273 & 0.084 \\
Prepelvic length & 0.71 & 0.409 & 0.176 & 0.679 \\
Pectoral-fin length & 2.479 & 0.130 & 1.283 & 0.269 \\
Pelvic-fin length & 0.001 & 0.981 & 7.309 & 0.013 \\
\hline
\end{tabular}


Table 5. Meristic data in Devario ahlanderi, D. browni, and D. cf. brown

\begin{tabular}{|c|c|c|c|c|c|c|c|c|c|c|}
\hline Branched dorsal-fin rays & 9.5 & 10.5 & & & & & & & & \\
\hline D. ahlanderi & 9 & 6 & & & & & & & & \\
\hline D. browni & 11 & 7 & & & & & & & & \\
\hline D. cf. browni & 16 & & & & & & & & & \\
\hline Branched anal-fin rays & 10.5 & 11.5 & 12.5 & & & & & & & \\
\hline D. ahlanderi & 1 & 14 & 0 & & & & & & & \\
\hline D. browni & 0 & 11 & 0 & & & & & & & \\
\hline D. cf. browni & & 9 & 1 & & & & & & & \\
\hline Pectoral-fin rays & 10 & 11 & 12 & & & & & & & \\
\hline D. ahlanderi & 7 & 4 & 1 & & & & & & & \\
\hline D. browni & 8 & 3 & 0 & & & & & & & \\
\hline D. cf. browni & 6 & 8 & 0 & & & & & & & \\
\hline Pelvic-fin rays & & 6 & 7 & & & & & & & \\
\hline D. ahlanderi & & 10 & 2 & & & & & & & \\
\hline D. browni & & 4 & 7 & & & & & & & \\
\hline D. cf. browni & & 4 & 10 & & & & & & & \\
\hline Predorsal scales & 13 & 14 & 15 & 16 & 17 & & & & & \\
\hline D. ahlanderi & 1 & 10 & 1 & & 0 & & & & & \\
\hline D. browni & 0 & 9 & 2 & & 0 & & & & & \\
\hline D. cf. browni & & 5 & 6 & 3 & 1 & & & & & \\
\hline $\begin{array}{l}\text { Circumpeduncular } \\
\text { scale rows }\end{array}$ & 12 & 14 & & & & & & & & \\
\hline D. ahlanderi & 0 & 12 & & & & & & & & \\
\hline D. browni & 11 & 0 & & & & & & & & \\
\hline D. cf. browni & 15 & 0 & & & & & & & & \\
\hline Scales in dorsoventral row & $1 / 2+6+1+2$ & $1 / 2+7+21 / 2$ & & & & & & & & \\
\hline D. ahlanderi & 3 & 10 & & & & & & & & \\
\hline D. browni & 1 & 8 & & & & & & & & \\
\hline D. cf. browni & 1 & 14 & & & & & & & & \\
\hline Lateral line scales & 25 & 26 & 27 & 28 & 29 & 30 & 31 & 32 & 33 & \\
\hline D. ahlanderi & & & & & 1 & 0 & 4 & 7 & 1 & \\
\hline D. browni & & & & & 0 & 4 & 2 & 2 & 1 & \\
\hline D. cf. browni & 2 & 2 & 1 & 1 & 3 & & 1 & 1 & 0 & \\
\hline Vertebrae & $15+18$ & $16+17$ & $16+18$ & $16+19$ & $17+16$ & $17+17$ & $17+18$ & $18+15$ & $18+16$ & $18+17$ \\
\hline D. ahlanderi & & & 2 & 1 & & & & & & \\
\hline D. browni & 1 & 3 & 2 & & 5 & 4 & 2 & 1 & 1 & 1 \\
\hline
\end{tabular}

